\title{
MODEL MATEMATIKA SIUC PADA KASUS KANKER SERVIKS DENGAN VAKSINASI
}

\author{
Khairunnisa Humolungo ${ }^{1 *}$, Rivka Paudi ${ }^{2}$ \\ 1,2,3 Jurusan Matematika, Universitas Negeri Gorontalo, Bone Bolango 96119, Indonesia \\ *Penulis Korespondensi. Email: nisahumolungo@gmail.com
}

\begin{abstract}
Abstrak
Artikel ini membahas tentang model SIUC pada kasus Kanker Serviks dengan mempertimbangkan vaksinasi. Adapun analisis yang dilakukan yaitu secara analitik dan numerik. Analisis secara analitik meliputi penentuan titik tetap bebas penyakit dan titik tetap endemik beserta sifat stabilitasnya. Selanjutnya dilakukan simulasi numerik untuk menguji hasil analitiknya. Dari hasil smulasi numerik diperoleh grafik yang menunjukkan bahwa solusi dari sistem yang bersifat stabil, dan dapat ditunjukkan bahwa vaksinasi pada kanker serviks memiliki dampak yang baik.
\end{abstract}

Kata Kunci: Kanker Serviks; Vaksinasi; Model SIUC

\section{Pendahuluan}

Kanker serviks atau kanker mulut rahim merupakan salah satu penyakit kronis yang menyerang bagian organ reproduksi wanita, tepatnya di daerah bagian bawah rahim. Penyakit ini disebabkan oleh Human Papilloma Virus (HPV) [1]. Studi epidemiologis pada infeksi HPV menetapkan peran virus ini sebagai penyebab utama kanker serviks. Diperkirakan bahwa infeksi HPV bertanggung jawab atas 500.000 kasus kanker serviks di seluruh dunia setiap tahun. Vaksinasi terhadap infeksi HPV merupakan cara yang efektif untuk menurunkan kejadian kanker serviks, terutama di kalangan wanita muda. Ketersediaan vaksin HPV memberikan kesempatan untuk menurunkan jumlah kasus penyakit di seluruh dunia yang di sebabkan oleh HPV. Sebenarnya, 2 vaksin pencegah infeksi HPV yang telah ditemukan sangat efisien dan cocok pada wanita. Beberapa model deterministik telah dikembangkan untuk menilai dampak potensial dari vaksinasi terhadap HPV [2].

Model penyebaran penyakit kanker serviks yang dikonstruksi menghasilkan persamaan model yang menggambarkan penyebaran penyakit kanker serviks pada populasi wanita rentan terhadap penyakit (Susceptible), populasi wanita yang terinfeksi penyakit (Infected) dan populasi wanita yang sembuh dari penyakit (recovered). Model tersebut merupakan model Susceptible-Infected-Recovered (SIR) yang dikembangkan oleh Kermack dan McKendrick [3]. Pada model lain dibahas penyebaran penyakit kanker serviks dengan jumlah populasi dibagi menjadi empat sub populasi yaitu, populasi rentan $(S)$, populasi terinfeksi $(I)$, populasi terinfeksi kemudian terjangkit penyakit $(C)$ dan populasi sembuh $(U)$ [4].

Pada artikel ini kami akan mengembangkan model dengan meninjau faktor-faktor yang ada pada penelitian sebelumnya. Disini kami akan menambahkan pemberian vaksin pada penyakit kanker serviks. Pada model ini digunakan beberapa variabel yaitu populasi (S) merupakan jumlah individu rentan, populasi (I) merupakan jumlah individu yang terinfeksi, populasi (U) merupakan jumlah individu yang sembuh, dan populasi (C) merupakan jumlah individu yang terinfeksi kemudian terjangkit penyakit. Maka dari itu penelitian ini berjudul "Analisis Stabilitas Model SIUC Dengan Pemberian Vaksin Pada Kanker Serviks".

Model yang diperoleh selanjutnya dilakukan analisis kestabilan penyebaran penyakit kanker serviks dengan titik tetap bebas penyakit dan titik tetap endemik. Simulasi numerik yang diperoleh menunjukkan kondisi saat $\mathrm{R}_{0}<1$, penyebaran penyakit kanker serviks dapat dicegah. Dengan melakukan vaksin maka nilai dari bilangan reproduksi dasar akan semakin kecil yang menunjukkan berkurangnya penyebaran kanker serviks dalam populasi.

\section{Metode Penelitian}

Metode yang digunakan pada penelitian ini yaitu:

a. Mengidentifikasi parameter dan variabel yang digunakan dalam model. 
b. Membuat asumsi yang melibatkan parameter dan variabel.

c. Model matematika dari parameter untuk setiap subpopulasi yang diperoleh dan asumsi-asumsi yang diberikan.

d. Menetukan titik kestabilan dari model yang diperoleh. Terdapat dua titik kestabilan, yaitu titik tetap bebas penyakit dan titik tetap berpenyakit.

e. Membuat simulasi numerik dengan menggunakan software Mathematica.

f. Menyimpulkan hasil yang diperoleh secara keseluruhan.

\section{Pembahasan}

\subsection{Model Matematika}

Pada model ini digunakan empat variabel, yakni: populasi rentan $(\boldsymbol{S})$ adalah populasi yang mempunyai kemungkinan untuk terinfeksi HPV, populasi terinfeksi (I) adalah populasi yang terinfeksi HPV, populasi sembuh dari penyakit $(\boldsymbol{U})$ adalah populasi yang terinfeksi HPV tetapi tidak terjangkit kanker serviks, dan populasi terinfeksi kemudian terjangkit penyakit $(\boldsymbol{C})$ adalah populasi yang terinfeksi HPV kemudian terjangkit kanker serviks. Adapun parameter yang digunaka adalah :
$b \quad$ : laju kelahiran
$v \quad$ : peluang terjadinya kontak antara individu rentan dan individu terinfeksi
$\alpha \quad$ : proporsi individu rentan yang tidak divaksinasi
$1-\alpha \quad$ : proporsi individu rentan yang divaksinasi
$\mu \quad$ : laju kematian alami
$\delta \quad$ : laju kematian akibat kanker serviks
$p \quad$ : proporsi individu yang terinfeksi virus HPV yang berlanjut ke kanker serviks.
$1-p \quad$ : proporsi individu yang terinfeksi virus HPV namun tidak berlanjut ke kanker serviks.

Beberapa asumsi yang digunakan adalah sebagai berikut:

1. Laju kelahiran tidak sama dengan laju kematian

2. Individu yang lahir masuk ke populasi rentan

3. Individu rentandivaksinasi

4. Individu rentan yang melakukan interaksi seksual dengan individu terinfeksi akan masuk ke kelas infected

5. Adanya peluang individu yang terinfeksi menjadisembuh alias tidak terinfeksi kanker serviks

6. Dan adanya peluang individu yang terinfeksi masuk ke kelas individu yang terinfeksi kanker serviks

7. Individu yang terkena kanker serviks tidak dapat sembuh

Dengan adanya variabel, parameter dan asumsi di atas, maka dinamika penyebaran penyakit campak dengan pengaruh migrasi dan penambahan imunisasi dapat dilihat pada Gambar 1.

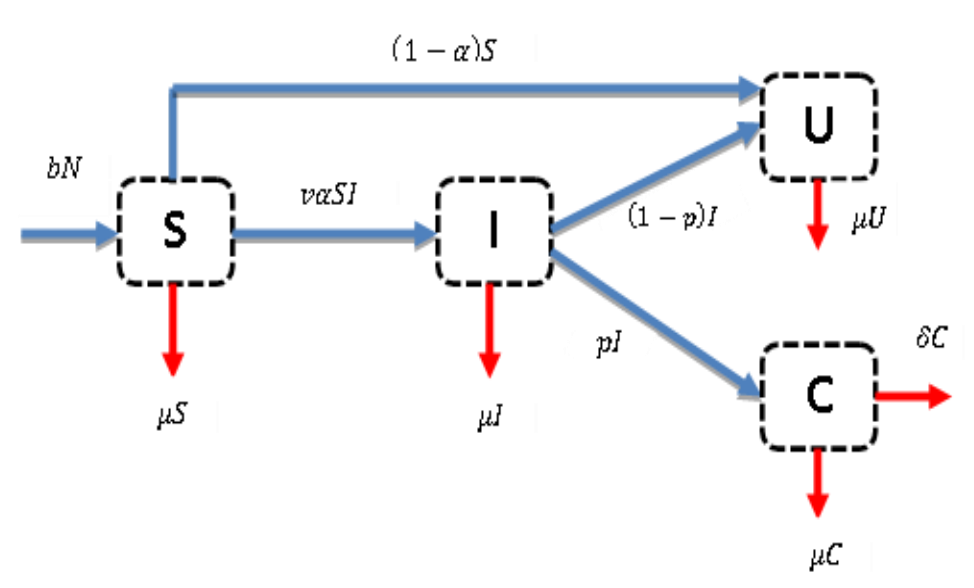

Gambar 1. Diagram compartment untuk penularan penyakit 
Sehingga model matematika dari diagram di atas dapat di uraikan sebagai berikut:

$$
\begin{aligned}
& \frac{d S}{d t}=b N-(1-\alpha) S-(\mu+v I \alpha) S \\
& \frac{d I}{d t}=v \alpha S I-(1-p) I-(p+\mu) I \\
& \frac{d U}{d t}=(1-p) I+(1-\alpha) S-\mu U \\
& \frac{d C}{d t}=p I-(\mu+\delta) C
\end{aligned}
$$

\subsection{Penentuan Titik Tetap}

\subsubsection{Titik Tetap bebas penyakit}

Titik tetap bebas penyakit terjadi jika $\boldsymbol{S}=\mathbf{0}$, dan $\boldsymbol{U}=0$ yang menunjukkan tidak terdapat populasi penyakit. Titik tetap bebas penyakit dapat dinyatakan dalam bentuk $\boldsymbol{E}_{\mathbf{1}}=(\boldsymbol{S}, \boldsymbol{I}, \boldsymbol{U}, \boldsymbol{C})$.

$$
E_{1}=(S, I, U, C)=\left(\frac{b}{(1-\alpha)+\mu}, 0,\left(\frac{b-\alpha b}{\mu-\alpha \mu+\mu^{2}}\right), 0\right)
$$

\subsubsection{Titik Tetap Penyakit}

Titik tetap penyakit dapat dinyatakan dalam bentuk $\boldsymbol{E}_{\mathbf{2}}=(\boldsymbol{S}, \boldsymbol{I}, \boldsymbol{U}, \boldsymbol{C})$. Berdasarkan dengan sistem persamaan pada model tersebut diperoleh:

$$
\begin{gathered}
\frac{\boldsymbol{d} \boldsymbol{S}}{\boldsymbol{d} \boldsymbol{t}}=\frac{\boldsymbol{d} \boldsymbol{I}}{\boldsymbol{d} \boldsymbol{t}}=\frac{\boldsymbol{d} \boldsymbol{U}}{\boldsymbol{d} \boldsymbol{t}}=\frac{\boldsymbol{d} \boldsymbol{C}}{\boldsymbol{d} \boldsymbol{t}}=\mathbf{0} \\
E_{2}=\left(\frac{1+\mu}{v \alpha}, \frac{-(1+\mu)^{2}+\alpha(1+b v+\mu)}{v \alpha(1+\mu)}, \frac{b v \alpha-\alpha \mu(1+\mu)+p(1+\mu)^{2}-p \alpha(1+b v+\mu)}{v \alpha \mu(1+\mu)}, \frac{p\left(-(1+\mu)^{2}+\alpha(1+b v+\mu)\right)}{v \alpha(1+\mu)(\delta+\mu)}\right)
\end{gathered}
$$

\subsection{AnalisiS Kestabilan Titik Tetap}

Untuk menganalisis kestabilan titik tetap suatu sistem persamaan diferensial nonlinier, dapat dilakukan dengan melinierkan persamaan diferensialnya. Analisis kestabilan titik tetap dapat ditentukan dengan cara menentukan nilai eigen dari matriks Jacobian sistem. Matriks Jacobian dari sistem adala :

$$
J=\left[\begin{array}{cccc}
-(1-\alpha)-(\mu+v i \alpha) & (v \alpha) s & 0 & 0 \\
v \alpha i & v \alpha s-(1-p)-(p+\mu) & 0 & 0 \\
(1-\alpha) & (1-p) & -\mu & 0 \\
0 & p & 0 & -(\mu+\delta)
\end{array}\right]
$$

Untuk memperoleh kestabilan sistem di titik $\boldsymbol{E}_{\mathbf{1}}$ terlebih dahulu dilakukan pelinearan disekitar titik tetap $\boldsymbol{E}_{\mathbf{1}}$ sehingga diperoleh matriks Jacobi untuk titik tetap bebas penyakit.

$$
J=\left[\begin{array}{cccc}
1+\alpha-\mu & -\frac{b v a}{1-\alpha+\mu} & 0 & 0 \\
0 & -1-\mu+-\frac{b v a}{1-\alpha+\mu} & 0 & 0 \\
(1-\alpha) & (1-p) & -\mu & 0 \\
0 & p & 0 & -\mu-\delta
\end{array}\right]
$$

Dari persamaan (1) diperoleh persamaan karakteristik

$$
\operatorname{det}(J-\lambda I)=0
$$

Dari persamaan karakteristik diperoleh nilai-nilai eigen dari matriks $J$, yaitu 


$$
\begin{aligned}
& \lambda_{1}=1+\alpha-\mu \\
& \lambda_{2}=-1-\mu-\frac{b v a}{1-\alpha+\mu} \\
& \lambda_{3}=-\mu \\
& \lambda_{3}=-\mu-\delta
\end{aligned}
$$

Kondisi stabil akan dicapai pada semua nilai eigen bernilai negatif, yaitu

$$
\lambda_{1}<\mathbf{0} \Leftrightarrow \mathbf{1}+\alpha-\mu<\mathbf{0} \Leftrightarrow \mu-\alpha<\mathbf{1}
$$

\subsection{Bilangan Reproduksi Dasar $\left(\boldsymbol{R}_{\mathbf{0}}\right)$}

Bilangan reproduksi yang dinotasikan dengan $\mathrm{R}_{0}$ adalah nilai harapan banyaknya infeksi tiap satuan waktu. Infeksi ini terjadi pada suatu populasi rentan yang dihasilkan oleh satu individu terinfeksi. Dari model yang telah dibentuk diperoleh bilangan Reproduksi dasar sebagai berikut:

$$
R_{0}=\frac{v \alpha b}{[(1-\alpha)+\mu][(1+p)+p+\mu]}
$$

$\mathrm{R}_{0}$ merupakan nilai ambang batas endemik yang akan menjadi tolak ukur tingkat penyebaran Penyakit Kanker Serviks dalam populasi. Kondisi yang memungkinkan dari bilangan reproduksi menurut Van Den Driessche \& Wathmough [3] adalah:

1. Jika $\mathrm{R}_{0}<1$, maka jumlah individu yang terinfeksi akan menurun pada setiap generasi, sehingga penyakit akan menghilang.

2. Jika $\mathrm{R}_{0}>1$, maka jumlah individu yang terinfeksi akan meningkat pada setiap generasi, sehingga penyakit akan meningkat.

\subsection{Simulasi Numerik}

\begin{tabular}{|c|c|c|}
\hline Parameter & Keterangan & Nilai \\
\hline$b$ & Laju Kelahiran & 0.0187 \\
\hline$\alpha$ & Proporsi individu rentan yang tidak divaksinasi & 0.31 \\
\hline$\mu$ & Laju kematian alami & $\frac{1}{0}$ \\
\hline$v$ & $\begin{array}{l}\text { Peluang terjadinya kontak antara individu rentan dan individu } \\
\text { terinfeksi }\end{array}$ & 0.6 \\
\hline$p$ & $\begin{array}{l}\text { Proporsi individu yang terinfeksi HPV yang berlanjut ke } \\
\text { kanker serviks }\end{array}$ & 0.7 \\
\hline$\delta$ & Laju kematian akibat kanker serviks & 0.0043 \\
\hline
\end{tabular}

Simulasi dilakukan dengan menggunakan nilai parameter yang terdapat pada Tabel 1. Nilai-nilai tersebut diperoleh berdasarkan data sekunder dan beberapa nilai parameter digunakan berdasarkan asumsi. Untuk melihat dinamika populasi berdasarkan nilai-nilai parameter yang telah ditentukan dapat menggunakan software Mathematica dengan nilai awal $S(0)=300, I(0)=20, U(0)=50, C(0)=75$.

Tabel 1. Parameter

Berdasarkan nilai-nilai parameter pada Tabel 1 di atas diperoleh yaitu $\mathrm{R}_{0}<1$. Dinamika penyebaran penyakit kanker serviks dengan vaksinasi disajikan pada Gambar 2. 


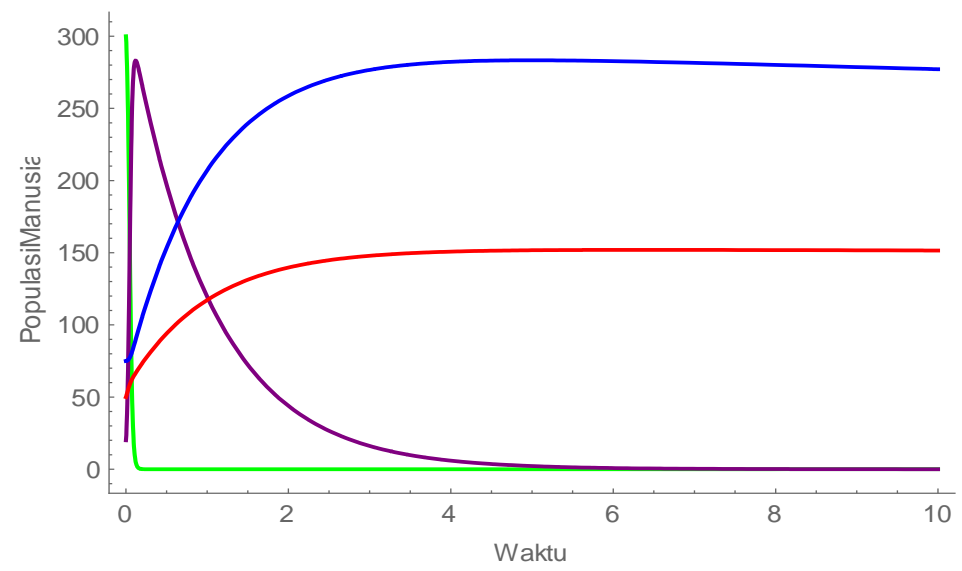

Gambar 2. Dinamika populasi pada kondisi $\mathrm{R}_{0}<1$

Simulasi model untuk nilai-nilai parameter tael 1 memberikan bilangan reproduksi dasar $\left(\mathrm{R}_{0}\right)$ sebesar 0.00209571. dilihat dari gambar 2 , pada kondisi $\mathrm{R}_{0}<1$ grafiknya akan menuju disekitar titik tetap bebas penyakit $E_{1}(S=300, I=20, U=50, C=75$. Hal ini dapat dikatakan bahwa penyebaran penyakit kanker serviks tidak terjadi atau penyebaran kanker serviks lama kelamaan menghilang dari populasi.

\section{Kesimpulan}

Dari sistem persamaan differensial tersebut diperoleh 1 titik ekuilibrium bebas penyakit yang stabil dan dengan melakukan vaksin maka $\mathrm{R}_{0}$ akan semakin kecil yang menunjukkan berkurangnya penyebaran penyakit dalam populasi. Hal ini dapat dikatakan bahwa penyebaran penyakit kanker serviks lama kelamaan menghilang dari populasi.

\section{Referensi}

[1] H. Hasnawati, R. Ratianingsih, and J. W. Puspita, "Analisis Kestabilan Model Matematika Pada Penyebaran Kanker Serviks Menggunakan Kriteria Routh-Hurwitz," Jurnal Ilmiah Matematika dan Terapan., vol. 14, no. 1, pp. 120-127, Juni, 2017.

[2] L. R. Majed. "A SIS Model for Human Papillomavirus Transmission," Institut de Cancerologie Gustave Roussy., pp. 27-35, 2010.

[3] Kermack, W, and Mc Kendrick, A, G, "A Contribution to the Mathematical Theory of Epidemics," Royal Society, 115: 700-721, 1927.

[4] U. N. Wulandari, "Analisis Model Epidemik MSEIR pada Penyebaran Penyakit Difteri," Universitas Jember, 2013. 